\title{
Memórias, Biografias e Histórias de Jornalistas
}

Vaniucha Moraes $^{1}$

Neste artigo analiso casos de jornalistas que tiveram passagem pela revista Realidade (1966/1968) e por jornais da imprensa alternativa (1970) e empreenderam a publicação de livros a respeito de suas histórias de vida sobretudo nas duas últimas décadas. Investigo a relação entre fontes biográficas e objetos de estudo, assim como a interação entre biografias e outras fontes de pesquisa. A fim de ilustrar a temática, incorporei ao estudo das biografias dos jornalistas resultados da pesquisa de campo realizada por meio de entrevistas com os jornalistas intelectuais remanescentes de Realidade. Em minha abordagem, inicio pela argumentação sobre o valor das biografias como documento histórico e na sequência procuro relacionar os princípios de produção das obras autobiográficas dos jornalistas referidos ao contexto de transformações no campo jornalístico.

Palavras-chave: História do Jornalismo; Revista Realidade; Sociologia da Cultura; Sociologia das Elites.

1 Doutoranda vinculada ao programa de Pós-Graduação em Sociologia Política, Universidade Federal de Santa Catarina. Mestre em Jornalismo pela UFSC. Jornalista e pesquisadora de temáticas como: história dos intelectuais e da imprensa brasileira; sociologia da cultura; sociologia das elites; jornalismo e literatura. Email: vaniucha1@yahoo.com.br 


\title{
Memories, Biographies and $\mathrm{H}$ istories of Journalists
}

\begin{abstract}
:
In this article I analyze cases of journalists who worked at Realidade magazine (1966/1968) and at newspapers from the Alternative Media (1970) and also undertook the publication of books about their own life especially in the last two decades. I investigate the relationship between biographical sources and objects of study, as well as the interaction between biographies and other research sources. To illustrate this theme, I've incorporated to the study of their biographies the results obtained in field research conducted through interviews with the remaining intellectual journalists of Realidade magazine. In my approach, I start by arguing about the value of the biographies as historical document and then I try to relate the principles of production of the autobiographical works of journalists referred to the context of changes in the journalism field.
\end{abstract}

Keywords: History of Journalism; Realidade magazine; Sociology of Culture; Sociology of Elites.

Tudo foi breve e definitivo.

Eis está gravado

não no ar, em mim,

que por minha vez escrevo, dissipo.

Carlos Drummond de Andrade

Em agosto de 2009, quando pesquisava a revista Realidade, fui à casa do jornalista Mylton Severiano para entrevistá-lo. Mylton era um dos remanescentes da equipe original da prestigiada publicação lançada no ano de 1966, em um momento de agitação cultural e princípio do período ditatorial brasileiro decorrente do golpe militar de março de 1964. Mylton contou-me que estava escrevendo um livro sobre Realidade. Estava em posse do arqui- 
vo pessoal de Paulo Patarra, editor-chefe e principal idealizador de Realidade, falecido em 2008. Como posteriormente descreveria em seu livro Realidade - a história da revista que virou len$d a$, o arquivo pessoal de Patarra era uma pilha de laudas em uma caixa de papelão amarelo da Kodak, antiga, de guardar ampliações $18 \times 24$, cheia de fotos, bilhetes, comunicados e um manuscrito "bomba", de agosto de 1968, dois meses antes de ser "promovido" a diretor de projetos especiais (SEVERIANO, 2013, p. 21). Mylton se refere ao afastamento de Patarra que serviu de estopim para um episódio de demissão coletiva na redação da revista e posterior debandada dos jornalistas para a hoje denominada Imprensa Alternativa de 1970. No dia seguinte à ocasião do meu encontro com o jornalista, este me envia por $e$-mail um fragmento transcrito do arquivo pessoal de Patarra. Uma "pensata" contendo as diretrizes do projeto editorial da revista Realidade elaborada por quem concebeu a ideia da publicação. Esse documento foi crucial para minha dissertação de mestrado do mesmo modo como o livro de Mylton está sendo importante para minha atual pesquisa sobre os jornalistas intelectuais.

A breve narrativa acima exemplifica alguns dos dilemas enfrentados em situações de pesquisa. No trabalho jornalístico é comum que se considere fonte primária o indivíduo que - representante ou não de um grupo ou instituição - forneça informação de primeira mão sobre um assunto. Por sua vez, as fontes secundárias são aquelas que funcionam no momento de elaboração de pautas e são formadas, sobretudo, por especialistas e experts. No trabalho historiográfico, o cenário se modifica. Consideram-se primárias as fontes relacionadas aos relatos dos fatos vividos ou testemunhados pelo autor, escritos por ele ou por alguém a quem ele tenha transmitido essas informações. No entanto, essa condição não implica que os documentos tenham que ser exatamente contemporâneos aos acontecimentos neles tratados, desde que os relatos partam de alguém que viveu ou testemunhou os fatos narrados. Cabe sublinhar a importância 
do contexto em que se dá o registro do documento, pois ele fornecerá várias informações ao historiador. Já as fontes secundárias são aquelas que tomam por base as fontes primárias para a realização de suas análises, comentários e impressões e, por isso, tendem a estar mais distanciadas em relação ao momento dos acontecimentos relatados. Do ponto de vista historiográfico, tanto a proposta editorial de Patarra para a revista Realidade extraída do arquivo pessoal do editor-chefe e as entrevistas concedidas a mim pelos próprios precursores da publicação, como o livro de Mylton Severiano são fontes primárias. Ainda que o relato de Mylton tenha sido produzido a partir de uma totalidade de documentos aos quais não tive acesso e tenha como suporte a escrita de um autor que traça a sua própria história de vida e de seus amigos remetendo a um tempo pretérito.

Neste artigo abordo a relação entre as fontes e meu objeto de pesquisa, isto é, a relação entre os relatos biográficos e memorialísticos e os seus autores jornalistas. Considero relatos biográficos e memorialísticos o conjunto de obras publicadas pelos jornalistas que compuseram a primeira equipe da emblemática revista Realidade (1966/1968) e que na década de 1970 integraram a redação de jornais da Imprensa Alternativa tais como Movimento, Ex, Grilo, Bondinho e Fotochoq (Kucinski, 2003, p. 37); considero também relatos biográficos as entrevistas concedidas a mim durante a pesquisa de campo. A investigação entre a relação existente entre as fontes referidas e seus autores torna possível evidenciar as condições de produção que deram origem às obras e suas motivações. Por meio dela também poderei convergir minha atenção a um novo objeto de investigação: casos de jornalistas que detém prestígio perante os seus pares e conquistaram reconhecimento como intelectuais. No presente trabalho minha atenção se volta às características das obras biográficas e memorialísticas do grupo de Realidade. Destaco que essas procuram corresponder a um modelo de jornalista que é consagrado pela historiografia da imprensa. Tal modelo pode ser identificado com a imagem do intelectual que atua como jorna- 
lista, escritor e militante político, mas cuja atuação jornalística sobrepõe-se sobre as demais sendo esta identidade profissional que rege as demais. Com relação às fontes de pesquisa, aponto suas características principais: algumas são livros de memória; outras são biografias produzidas por companheiros de jornada na profissão; e há também livros que se propõem a contar a história de meios impressos (jornais e revistas) consagrados no campo da produção cultural.

Em síntese, o presente artigo tem como objetivo estabelecer o diálogo das biografias e memórias com outros tipos de fontes, especificamente, as informações obtidas em pesquisa de campo efetivada por meio das entrevistas concedidas a mim pelos jornalistas remanescentes da revista Realidade. É por meio da confluência entre a diversidade de fontes e suas respectivas condições de produção que as questões relativas ao registro da memória e história poderão ser abordadas, bem como, relacionadas às transformações na produção cultural em geral e no mercado profissional jornalístico em particular.

\section{M emórias corporativas e memórias de amigos}

Antes de caracterizar as fontes citadas é necessário revisitar como se deu o início do meu contato com as biografias e memórias dos jornalistas da revista Realidade. Tais leituras começaram quando eu pesquisava a publicação e os seus precursores. Desde então venho reconhecendo a remissão recorrente à figura do jornalista intelectual memorialista e sua associação com a marca da cultuada revista, uma publicação cuja dimensão simbólica atrelada à década de 1960 levou Millôr Fernandes a batizar a juventude daquela época como "geração Realidade" (FARO, 1999, p. 84).

Dada sua importância para atual argumentação, retomo brevemente meu objeto de estudo efetivado no mestrado. A revista 
Realidade, primeira experiência da Editora Abril em publicações de informação geral, existiu por dez anos consecutivos, de 1966 a 1976. Seu auge, porém, foram os quatro primeiros anos, de 1966 a 1968, período em que se destacou pela ousadia na linguagem e na abordagem temática. Em sintonia com a efervescência cultural daquele momento, a revista abordou toda sorte de polêmicas que agitavam aqueles anos da década de 1960. Era essencialmente uma revista de reportagens. Grande parte delas, redigidas em primeira pessoa. 0 resultado eram reportagens literárias fruto de pesquisas de imersão que, por vezes, duravam meses a fio. Nesse sentido, a revista se beneficiou dos estertores do intervalo democrático para contestar a moral vigente e o Estado autoritário em gradativo recrudescimento do golpe militar. Isto é, nos primeiros quatro anos e auge da revista, o Ato Institucional $\mathrm{n} \times 5$ ainda não havia sido promulgado. Entretanto, já na segunda metade do ano de 1968 a equipe responsável pala linha editorial adotada já se encontrava fragmentada em função do contexto de pressão política e do investimento que a Editora Abril estava fazendo em seu próximo lançamento, a revista Veja, realizado em setembro de 1968. Após 1968, Realidade sofreu um gradativo processo de descaracterização em seu projeto inicial e seguiu perdendo a essência contestadora e também o seu público. Teve reduzido o seu número de tiragens até finalmente parar de ser impressa em 1976. Porém, os momentos áureos de Realidade permaneceram na memória de profissionais de imprensa, dos leitores e, sobretudo, nas mentes daqueles que se encarregaram de fixá-la nos registros da história da imprensa brasileira por meio de autobiografias e trabalhos científicos produzidos décadas depois.

Muitos foram os trabalhos acadêmicos que abordaram direta ou indiretamente a revista Realidade. 0 primeiro foi uma tese de doutoramento realizada em 1988, de autoria de Maria Terezinha Tagé Dias Fernandes, denominada Jorge Andrade, Repórter Asmodeu: leitura do discurso jornalístico de autor na revista Rea- 
lidade. Em 1991, Bernardo Kucinski, defendeu a tese Jornalistas e Revolucionários: nos tempos da imprensa alternativa. Nela o autor posiciona a revista Realidade como uma importante matriz da imprensa alternativa na década de 1970. Em seguida, em 1999, José Salvador Faro produz Realidade 1966-1968: tempo de reportagem na imprensa brasileira. Faro posiciona a revista no centro de seu trabalho e a classifica como um marco na história da reportagem na imprensa nacional. Em 1997, Adalberto Leister Filho apresentou trabalho de iniciação científica denominado: Realidade em revista: a revista Realidade, a memória dos jornalistas de uma publicação revolucionária (1965-1968). 0 autor buscou recuperar o caráter considerado "revolucionário" da revista a partir de depoimentos de jornalistas que participaram da equipe original. Leister deu sequência à sua pesquisa em uma dissertação de mestrado defendida em 2003, denominada Entre o sonho e a realidade: pioneirismo, ascensão e decadência da revista Realidade (1966-1976). Outros tantos trabalhos científicos utilizaram a publicação como eixo, como a dissertação de Letícia Nunes Góes Moraes, de 2001, denominada A dança efêmera dos leitores missivistas da revista Realidade (1966-1968), em que a autora analisa a seção de cartas da revista. Em 2010, defendi a dissertação Realidade (Re) vista: o papel do intelectual na concepção de um projeto revolucionário na qual busquei compreender o motivo do recorrentemente citado caráter revolucionário da revista. Esse trabalho foi realizado por meio de uma investigação que envolveu pesquisa documental nas edições dos quatro primeiros anos aliada à pesquisa de campo na qual entrevistei os precursores de Realidade. Na ocasião, pude aferir que Realidade havia sido resultado de uma comunhão de fatores: o contexto sócio-histórico, a sinergia da redação e a formação intelectual dos seus jornalistas. Entretanto, é preciso frisar que a influência do contexto para o surgimento de uma experiência editorial como Realidade situa a revista do lado de fora do próprio contexto, sendo assim, uma avaliação feita a posteriori quando a publicação já era considerada um marco na história da imprensa nacional. 
Após essa extensa lista de exemplos de pesquisas que direta ou indiretamente abordaram Realidade - embora sem abarcar em sua totalidade a quantidade de trabalhos realizados em função dos limites de espaço para um artigo - é necessário destacar a título de informação: entre os pesquisadores muitos tiveram formação inicial em jornalismo, atuaram como jornalistas ou são professores na área de comunicação, como por exemplo, Bernardo Kucinski, J. S. Faro, Letícia Nunes Góes e Adalberto Leister Filho.

No transcorrer do processo de levantamento de dados durante o mestrado tive que recorrer ao recurso das biografias dos jornalistas com passagem por Realidade e assim pude identificar alguns traços característicos de seus autores e obras. Enquanto Realidade conquistava cada vez mais prestígio como objeto de pesquisa no âmbito acadêmico, os jornalistas que fizeram história fazendo Realidade, também redigiam seus livros de memórias. Assim, o que esse conjunto de obras informa é a convergência entre os interesses de pesquisa dos acadêmicos e a vontade de testemunhar dos sujeitos históricos.

João Antônio, escritor e jornalista de Realidade, já havia publicado na coletânea de contos Malhação do Judas Carioca, de 1975, um conto reportagem sobre o cotidiano do cais de Santos intitulado "Cais" e originalmente publicado sob o título "Um dia no cais" na edição de novembro de 1968 de Realidade. Em 2005, João Antônio foi biografado por Mylton Severiano, amigo e companheiro dos tempos de Realidade, em "Paixão de João Antônio". Os exemplos mostram a simbiose entre produção jornalística e literária e a permeabilidade entre seus agentes. Porém, antes, em 1998, José Hamilton Ribeiro publica o livro Jornalistas: 1937 a 1997 - história da imprensa de São Paulo vista pelos que batalham laudas (terminais), câmeras e microfones, livro que marcava o aniversário de 60 anos do Sindicato dos Jornalistas de São Paulo no qual consta referência à Realidade. Na sequência foram publicadas as seguintes obras, que em geral consistem na narra- 
tiva de um indivíduo inserido em seu grupo, entremeada com a história da imprensa e do país, sendo elas: Eu é um outro: autobiografia de Roberto Freire, de 2002; Cicatriz da reportagem: 13 histórias que fizeram um repórter, de 2007, de Carlos Azevedo; Realidade Re-vista, de José Hamilton Ribeiro e José Carlos Marão, de 2010; e Realidade - a revista que virou lenda, de Mylton Severiano, de 2013. Realidade e seus protagonistas também fundaram projetos de comunicação como a Caros Amigos, revista que em maio de 2008 publicou uma edição especial em função do falecimento do jornalista Sérgio de Souza. Sérgio havia sido editor de texto de Realidade e na década de 1970 capitaneou várias produções da Imprensa Alternativa, sendo uma referência para os seus amigos, motivos para se dedicar uma edição integral a ele.

Nota-se que os livros mencionados têm algumas características em comum: neles os autores relatam suas memórias e nelas incluem suas passagens pela revista Realidade e pela Imprensa Alternativa; há uma recorrente menção à história do grupo como história vivida em conjunto e assim é frequente o uso do pronome "nós" para designar essa memória coletiva, por sua vez, associada à história nacional o que justifica que um amigo biografe o outro ou escreva sobre a revista; outra característica é o fato de seus autores serem escritores profissionais que atuaram na imprensa e também já publicaram livros. São, portanto indivíduos que no transcorrer nos anos marcaram suas trajetórias pelo exercício profissional da escrita no jornalismo e na literatura.

Há nas obras referidas uma remissão a nomes prestigiados do jornalismo e da literatura, bem como, é reiterado o modelo do jornalista escritor e cronista social, o profissional jornalista que além de escritor não se isenta de pensar a realidade nacional. 0 escritor e jornalista Roberto Freire relata em autobiografia sua formação intelectual e o encontro com Monteiro Lobato e demais intelectuais reconhecidos durante a infância na casa de um amigo: 
...à noite, em sua casa, pude conhecer alguns dos principais intelectuais de São Paulo naquela época, como Mário de Andrade, Guilherme de Almeida, Menotti Del Picchia, Oswald de Andrade e Monteiro Lobato. 0 encontro como Monteiro Lobato foi alo fundamental e inesquecível. Impressionava-me muito ver de perto o escritor que mais admirava e de quem havia lido toda a obra publicada até aquela época. Seus livros complementavam meus conhecimentos rudimentares sobre humanidades ensinadas na escola e, sobretudo, agradava-me demais seu estilo bem humorado e crítico... (FREIRE, 2002, p. 26)

Nesse trecho Freire expõe seu processo de aquisição da bagagem cultural, em outras palavras, o seu capital cultural em potencial e ressalta a rede de contatos intelectuais que começava a ser tecida desde a juventude. Freire foi considerado um dos mentores das grandes ideias que surgiram em Realidade e exercia forte influência sobre os demais, não coincidentemente, sua admiração pela obra de Monteiro Lobato é compartilhada e citada como referência na formação intelectual em todas as entrevistas concedidas a mim e também constam nas memórias publicadas em livro. Na época em que entrevistei Mylton Severiano, o jornalista fazia uma série de entrevistas com os amigos para redigir um livro sobre a Revista e sua equipe inicial. Quando perguntado a respeito de sua formação intelectual Mylton cita Monteiro Lobato como uma referência comum a todos: "Monteiro Lobato é recorrente. Entrevistei todos os sobreviventes, praticamente, por causa do livro. Invariavelmente, na infância, Monteiro Lobato. Bom texto, mordaz. A Emília era o Lobato. Havia o espírito questionador" (MORAES, 2010, p. 144). 0 depoimento de Carlos Azevedo corrobora o do colega:

Depois uma coisa que eu tenho que eu acho que marcou a minha geração toda foi Monteiro Lobato, com aquela coleção infantil. Eu acho que aquilo ali foi a universidade de muita gente, a minha pelo menos, ou aquilo que eu entendia de mundo na época. Atribuo a Monteiro Lobato uma postura, uma influência revolucionária sob a classe média da época. Eu acho que foi um grande revolucionário. E a lite- 
ratura infantil dele transformou cabeças, a minha inclusive (MORAES, 2010, 175).

A formação intelectual no jornalismo, na vivência da profissão e por interesse pessoal é salientado pelos entrevistados, o que se contrapõe à formação via escolar e ao diploma. Como veremos adiante, o elogio ao autodidatismo tem a ver com o conflito entre os jornalistas por vocação e os jornalistas por formação universitária um dos elementos conjunturais significativos das mudanças no mercado profissional nas últimas décadas. Isto é, pode-se compreender que o registro biográfico é entendido mais pelo contexto de produção do que pela época que faz referência, como demonstra o trecho seguinte da obra de Azevedo:

Aqui faço uma generalização, correndo os riscos que as generalizações oferecem. Pelo que me lembro, era uma turma mais intuitiva que estudiosa, autodidata - só uns poucos tinham curso universitário completo, alguns estudaram só o primário -, anárquica, indisciplinada que leu menos Gilberto Freire e Sérgio Buarque do Holanda, e mais Machado de Assis, Monteiro Lobato (muito Monteiro Lobato, esse grande subversivo!), Mário de Andrade, Lins do Rego, Jorge Amado, Graciliano Ramos, Drummond, João Cabral, Manuel Bandeira. Que tomou um susto e se apaixonou por Guimarães Rosa. Que lia João Antônio e até o incorporou à redação... (AZEVEDO, 2007, p. 104).

João Antônio mencionado acima por Azevedo era um jornalista experiente no período e por algum tempo conciliou o trabalho no Jornal do Brasil e em Realidade, publicação na qual desenvolveria o gênero conto-reportagem. João Antônio foi um escritor que obteve reconhecimento imediato da crítica literária logo após a estreia e chegou a conquistar o Jabuti na categoria contos com o livro Malagueta, Perus e Bacanaço em 1963. Enaltecido pelo emprego da linguagem coloquial e por dar protagonismo aos párias e marginalizados sociais em seus contos, João Antônio tinha fixação por outro jornalista e escritor que exercia forte 
influência sobre o seu trabalho. À Lima Barreto dedicou vários de seus livros tendo inclusive produzido um romance histórico sobre ele, intitulado Calvário e Porres do pingente Afonso Henrique de Lima Barreto, lançado em 1974. Em comum, Lima Barreto e João Antônio compartilhavam a posição de escritores malditos em suas respectivas épocas. Assim, ao redigir um romance biográfico sobre Lima Barreto, João Antônio realiza ao mesmo tempo dois feitos importantes: reitera o prestígio do seu ídolo literário e enlaça sua trajetória intelectual à do escritor carioca. A construção da memória corporativa dos jornalistas escritores será levada adiante pelo amigo Mylton Severiano que produziu a biografia intitulada "Paixão de João Antônio", lançada em 2005. Obra ancorada na relação epistolar mantida com o amigo escritor durante vários anos, a biografia do escritor paulistano também consagra o nome de Severiano à medida entrelaça as duas trajetórias intelectuais no registro histórico da produção cultural nacional. 0 encontro entre dois companheiros é assim contado na biografia escrita por Mylton Severiano:

Foi Otoniel Santos Pereira quem me alertou para o esplendor daquele fruto na árvore de nossa geração. Corria 1963, trabalhávamos na Folha de S. Paulo. Otoniel falou do colega que ia lançar o primeiro livro, Malgueta, Perus e Bacanço. Bom às baldas, como se dizia (...) No anoitecer de 21 de junho de 1963 passei na Livraria Teixeira, Rua Marconi, 40, centro de São Paulo. A "terra de gigantes". Chuviscava frio. A capital paulista beirava 4 milhões de habitantes, vinha dobrado a cada década desde fins dos anos 1930. Inchava de migrantes, como eu, chegado de Marília em 1960 (...) Tímido, comprei o livro e não pedi autógrafo. Em torno do estreante de 26 anos, gente importante: a poeta Ilka Laurito Brunhilde, que havia estreado aos 23 anos, com Caminho, e agora dirigia o Departamento de Cinema e Educação da Cinemateca Brasileira; o filho de Graciliano, publicitário e escritor Ricardo Ramos; talvez o crítico Paulo Émílio Sales Gomes, casado como Lígia Fagundes Telles; certamente o jornalista, escritor e poeta, agitador cultural Sérgio Milliet, que apadrinhou Mário de Andrade, conseguiu ali uma sala 
com máquina de escrever para ele refazer o livro de estreia - um incêndio havia queimado os originais, como vamos ver o irmão Virgínio contar. 0 Milliet que o jovem escritor retrataria saudoso treze anos mais tarde, em Casa de Loucos (SEVERIANO, 2005, p.31-34).

No trecho citado acima Mylton menciona a dificuldade do amigo quando os manuscritos de seu livro de estreia foram queimados em função de um incêndio ocorrido na casa onde residia com a família. Dificuldade contornada com o auxílio de Sérgio Milliet que apadrinhou João Antônio no início de sua carreira como escritor e também pelo fato de sua obra ter obtido boa acolhida por parte da elite intelectual paulistana da época. A narrativa de Mylton também associa as identidades artísticas de Lima Barreto e João Antônio, em um capítulo intitulado "Tempos de Realidade", assim descreve o amigo: De Lima Barreto, tinha a pegada, a postura ao lado dos humilhados e ofendidos (Severiano, 2005. p. 59). Nesse capítulo Mylton recorda o período na redação de Realidade, a parceria com João Antônio e cita uma infindável lista de escritores que começaram a vida no jornalismo ou do jornalismo fizeram uma segunda profissão, como: Nelson Rodrigues, Graciliano Ramos, Carlos Heitor Cony, Antônio Callado, Euclides da Cunha, Lima Barreto e João Antônio. É também em "Paixão de João Antônio" que Mylton Severiano começa a tecer o registro histórico do grupo de jornalistas à qual fazia parte junto ao nome da revista Realidade e publicá-las em livros. Ainda na mesma biografia Mylton descreve a impressão de João Antônio sobre o período da revista:

A revista que nos transformou em "grifes", no dizer de Paulo Patarra, e que ainda em 2005 levava estudiosos a procurar os "sobreviventes" para compor suas teses em cursos de comunicação, cobrou preço alto a JA - 'me custou ter de morar na Boca do Lixo (Rua Vitória) com mulher e filho pequeno. E para aturar tudo aquilo precisei de porres degradantes'. Para ele, não havia nada de 'anos loucos', a não ser 'o tamanho na grana que os patrões ganhavam com o nosso talento, 
sacrifício, noites sem dormir, serões na redação e frustração geral' (SEVERIANO, 2005, p. 59).

Após o ano de 2005, data da publicação da biografia sobre João Antônio, Mylton Severiano e os "sobreviventes" receberam mais pesquisadores e a revista consolidou seu prestígio em grande parte em função dos trabalhos acadêmicos realizados nas mais diversas áreas. Diante da profusão dos trabalhos científicos publicados e dos constantes contatos para entrevistas, vários remanescentes de Realidade tomaram a iniciativa de contar suas próprias histórias. A partir dos anos 2000 começam a ser publicados livros de memórias profissionais como "Cicatriz de Reportagem - 13 histórias que fizeram um repórter" (2007) de Carlos Azevedo no qual o autor republica cinco das grandes reportagens feitas durante $o$ período de Realidade e retoma a trajetória do grupo que a produziu durante o seu período áureo de 1966 a 1968. Em sua autobiografia o escritor, médico, psicanalista e jornalista Roberto Freire, também revive o momento passado na redação.

Nossa realidade política, na época, 1965, era terrível. Paulo Patarra confiou na inteligência dos jornalistas convidados a participar de "Realidade", na adoção de táticas e de estratégias para exercerem sua sinceridade e revelarem a verdade sobre os problemas da vida brasileira, sem ser necessário denunciar de modo direto e nominativo suas principais causas políticas. Eles conheciam a violência da censura, especialmente sobre a imprensa. Esse ponto, verdadeiro fio da navalha nos relatos e no conteúdo das matérias, talvez haja sido um dos principais motivos que permitiram a sobrevivência da revista no auge da repressão policial e militar daquela época (FREIRE, 2002, p. 245).

No trecho supracitado, Freire comenta como a engenhosidade da redação se sobrepunha aos transtornos causados pelo regime militar, especialmente, à censura. É com esse tom - que mescla o elogio à sintonia e à bravura do grupo às dificuldades encontradas perante poderes opressores representados pela chefia da empresa 
ou pelo governo ditatorial - que foram redigidas outras obras cuja temática central é a própria revista Realidade, entre elas Realidade Re-vista de José Hamilton Ribeiro e José Carlos Marão e Realidade - a revista que virou lenda de Mylton Severiano. 0 livro memorialístico de Severiano, em especial, resgata as histórias e trajetórias dos integrantes da equipe original e desvela os laços de sociabilidade constituídos ao longo das carreiras e que mantiveram relativamente unidos os seus participantes. A origem social de cada um é retomada e desse modo fica evidenciado que a maioria dos integrantes do grupo é constituída por indivíduos oriundos da região Sudeste, em geral do Estado de São Paulo, especialmente de municípios do interior. Embora haja casos de indivíduos que vieram de Minas Gerais e também da região Nordeste. Entre eles, dois vieram da mesma cidade e começaram a vida profissional juntos em auxílio mútuo na conquista de oportunidades de trabalho. Em geral, eles tiveram relativa boa educação e acesso aos livros e outros produtos culturais. É uma constante a trajetória pessoal em que o indivíduo possui parte da família na capital e parte da família no interior, ou seja, pode-se dizer que a equipe inicial da revista Realidade era formada por pessoas urbanizadas e, portanto já familiarizadas com as produções culturais dos grandes centros. Em um trecho de seu livro de memórias, Azevedo traça o perfil do grupo que formou a equipe precursora da revista Realidade e que posteriormente seria solicitado para dar entrevistas para vários pesquisadores.

Eram muito diferentes, vinham de lugares situações, condições culturais e políticas diversas, mas na sua grande maioria originários da mesma classe média do Sudeste (...) partilhavam de uma mesma herança de ideias desenvolvidas no país a partir da década de 30, período de brilho da nossa literatura, da música popular e erudita, das artes plásticas, cujas raízes tinham a ver com a urbanização, a industrialização (AZEVEDO, 2007, p. 103).

Pude depreender do exame nos relatos biográficos outras características significativas. Foram recorrentemente citadas a coesão 
e a sintonia do grupo bem como a referência a uma história individual atrelada a uma história coletiva exemplificada pelo uso recorrente do pronome nós como designação afetiva do grupo. Isso pode decorrer das várias entrevistas que eles concederam aos pesquisadores que os procuraram em razão do reconhecimento de Realidade e da Imprensa Alternativa como marcos da atuação do jornalista enquanto intelectual, como sugere o relato do jornalista Carlos Azevedo.

A gente imaginava uma forma diferente de fazer jornalismo, achávamos que tínhamos que fazer um jornalismo mais ligado aos problemas do povo, mais ligado aos problemas da população, isso tudo, assim, muito improvisadamente, não como uma coisa planejada, discutida. Mas achávamos isso (...) que o jornalismo tinha que transformar. E foi com essa mentalidade que a gente foi parar na revista Realidade (MORAES, 2010, p. 176)

A memória individual também aparece como memória coletiva posto que vinculada à história da imprensa e também do país, uma vez que remonta ao período ditatorial de censura aos meios de comunicação. A experiência na revista Realidade e na Imprensa Alternativa aparece como marco temporal em muitos dos relatos. Posso destacar ainda que as datas das publicações (os anos 2000) coincidem com um momento de crise e de redefinição da identidade jornalística. A questão da exigência de diploma para exercer a profissão aparece como marco temporal escamoteado, embora presente na defesa do autodidatismo no depoimento de Severiano.

Eis um flagrante da turma: andar de ônibus devorando letras. Autodidatas. Serjão [Sérgio de Souza, editor de texto de Realidade], aos 12 anos, quando a mãe expulsou de casa o marido adúltero, saiu do colégio e foi trabalhar. Fez-se devorando livros, filmes, formado, como todos nós, na escola da vida (...) Não havia exigência do diploma para exercer o 
jornalismo. Realidade não teria sido possível se já existisse a invencionice, gestada no auge da escalada fascistoide da ditadura. Quase todos éramos filhos de classe média baixa ou da pobreza. Havia filho de ferroviário, telefonista desquitada, professor, sapateiro, comerciante, barbeiro, chofer de praça, contador, funcionário público. Vários trabalhavam em banco e, no fim do expediente partiam para a vocação (SEVERIANO, 2013, p. 26).

A referência à formação intelectual feita autonomamente está associada ao capital simbólico vinculado à identidade tradicional do jornalista. 0 sentimento de identidade coletiva e a coesão daquele grupo de amigos formado antes mesmo de Realidade (Mylton Severiano e Woile Guimarães se conheceram na infância, outros no início da carreira) chamou a atenção de Kucinski, segundo o qual a principal característica desse grupo era a autonomia e sua conduta peculiar de desprezo às convenções e tradições, o que fez ser considerado um das mais demarcadas 'panelas' do jornalismo brasileiro sob o aspecto do código de comportamento (KUCINSKI, 2003, p. 232). A coesão do grupo é retratada no trecho da autobiografia do jornalista e escritor Roberto Freire:

\footnotetext{
Nossa equipe em Realidade e, depois, na Arte e Comunicação, era composta pelos seguintes jornalistas fundadores. Outros se associaram a nós em várias ocasiões, mas por curtos períodos e não podem ser considerados realmente parte da liderança que criou e conduziu nosso jornalismo paixão: Paulo Patarra, Sérgio de Souza, Narciso Kalili, José Hamilton Ribeiro, Hamilton de Almeida, Carlos Azevedo, José Carlos Marão, Woile Guimarães, Eurico Andrade e eu ...(FREIRE, 2002, p. 259).
}

Em suas trajetórias profissionais, os jornalistas da extinta revista Realidade atravessaram o panorama de mudanças no jornalismo. Depreendem-se, de seus relatos, referências ao capital simbólico da experiência de vida através do jornalismo. Por outro lado, por terem vivenciado o auge de modernização da imprensa, também fazem referência à dimensão técnica e não 
apenas vocacional do ofício. Atualmente José Hamilton Ribeiro, José Carlos Marão, Carlos Azevedo e Frei Betto parecem ter estabelecido suas carreiras também como escritores profissionais. Os falecidos Roberto Freire, João Antônio e Mylton Severiano, embora tenham sido considerados escritores marginais quando vivos, nos dias atuais são escritores reconhecidos. Ao contrastar o percurso profissional e intelectual dos jornalistas referidos com as mudanças ocorridas na produção cultural posso inferir que as mudanças no mercado profissional dos jornalistas possuem relação intrínseca com a crescente onda de publicações de memórias de antigos jornalistas. É possível inferir acerca dos vínculos entre as concepções de identidade e memória jornalística. 0 crescimento do número de compêndios históricos a respeito dos nomes e veículos da imprensa de notoriedade é demonstrativo das mudanças ocorridas no campo. Trata-se de uma mudança na modalidade de registro da história do jornalismo, como argumenta Bergamo:

Não é mais a reportagem, fronteira entre uma memória individual e uma coletiva e principal definidora da profissão, que permite ao jornalismo encontrar-se no passado ao nele se deparar com a sua própria narrativa, mas sim o registro dessas vidas e trajetórias exemplares e de sua passagem pelo jornalismo (BERGAMO, 2011, p. 257).

0 que se evidencia é o conflito entre duas formas de registro da memória, o primeiro por meio das reportagens e o segundo pelo registro histórico dos casos consagrados. A transformação da memória em história encerra a forma como os jornalistas se veem e intencionam ser vistos. Assim, tem-se que as transformações ocorridas em âmbito geral no mercado de bens culturais, e por consequência no jornalismo, teve como desdobramento a mudança na constituição identitária do jornalista. A reunião dos dados levantados pela pesquisa demonstrou a marca do conflito existente entre duas identidades jornalísticas que se opõem: a identidade consagrada por uma historiografia tradicional, que 
valoriza a figura do repórter, e o gênero reportagem como paradigmático da profissão, e uma nova identidade criada pelas contingências do mercado que aos poucos se consolida, a do jornalista técnico em oposição ao jornalista humanista.

\section{H istória e Memória: individual e coletiva}

Eleger biografias e memórias como fontes primárias suscita algumas questões relevantes. A biografia advém do mundo grego antigo, período em que era importante descrever a história de vida de alguém sublinhando sua singularidade moral ou política. 0 costume se prolongou no mundo medieval por meio das hagiografias que se propunham a relatar as vidas dos santos. A biografia como fonte histórica encerra certa prudência e remonta a uma discussão que por vezes parece superada. Trata-se da pretensão de fidedignidade desse tipo de registro. Entretanto, pode-se destacar que hoje é unânime a ideia segundo a qual não há uma verdade única, sendo que para cada fato podem existir várias versões. Isso porque toda história é uma construção e o resultado da perspectiva do autor, do seu tempo e espaço, sendo marcada também por instituições e grupos. Além disso, é patente a impossibilidade de reduzir toda a singularidade de uma vida, o absoluto do "eu" em uma narrativa biográfica. De acordo com Borges, a preocupação atual é com o verossímil, com o que nos parece verdadeiro, o que é possível ou provável (BORGES, 2010, p. 216).

Em segundo lugar, o status da biografia histórica remete à história política, esta reconhecida por tratar de trajetórias dos indivíduos mais proeminentes. Os historiadores integrantes da escola dos Annales no período entre 1950 e 1970 passaram a rejeitar essa forma de vestígio dos notáveis pelo fato de suas biografias não permitirem a apreensão dos grandes conjuntos econômicos e sociais. Assim, as biografias foram deixadas de fora de uma história científica centrada em aspectos gerais. Mas, à medida que 
foram arrefecendo os ideais de apreensão de uma história total que ambicionavam a compreensão global de uma sociedade e evolução, as biografias readquiriram sua legitimidade como documento histórico, pois tornava-se mais interessante compreender, a partir de casos concretos, os funcionamentos sociais, culturais e religiosos (PROST, 2008, p. 81).

A história pode ser escrita a partir de várias fontes. Sua matéria-prima é diversa e compreende arquivos, diários, selos, objetos de uso pessoal e até a literatura, a música e a arquitetura de uma determinada época. Porém, na epistemologia disciplinar diz-se que a memória é a matriz da história; a memória que é tornada testemunho, a memória inscrita, arquivada, destinada aos arquivos e por fim à historiografia, à escrita da história. Esta epistemologia preconiza que a história se autonomizou ou se institucionalizou como disciplina a partir do momento em que se destacou da memória e da oralidade do testemunho. 0 arquivo, fonte privilegiada para o historiador, é o resultado do testemunho inscrito tornado documento histórico.

Assim como os arquivos, as biografias são o registro de uma época e podem ser consideradas fontes primárias de acordo com a sua importância para determinada pesquisa. No entanto, pelo fato de representar um ponto de vista de alguém ou de um grupo a biografia se assemelha a uma "prestação de contas" e reclama para si uma autoridade que é negada tanto pela História como pela Literatura. Além disso, quando se trata de biografias é recorrente a menção - seja implícita ou explícita sobre a questão da verdade. Deste debate emergem duas atitudes antagônicas: se por um lado existe um pacto com a verdade dos enunciados e, nesse caso, a biografia aparece como um valor reivindicado; por outro lado, a biografia é considerada uma construção imaginária e uma realidade recusada. Porém, o fato de a identidade individual ser constituída por uma narrativa não demonstra que esta seja ficcional. Para Lejeune, seguir as linhas da narrativa é ser fiel à verdade de cada um pois "se a 
identidade é um imaginário, a autobiografia que corresponde a esse imaginário está do lado da verdade" (2008, p. 104). Lejeune assevera que a criação literária e ficcional pode ser autobiográfica e que as biografias podem ser ficcionais sem com isso comprometer a "verdade" do seu autor.

A discussão a respeito da construção identitária presente nos relatos biográficos é perpassa pelo debate a respeito da memória. A memória é tanto um fenômeno individual como social. Pode-se dizer que o testemunho ganhou projeção a partir da difusão das pesquisas com base no método da História Oral. Por meio dos testemunhos muito se investigou sobre os processos de projeção e transferência da memória que consistiam basicamente na imbricação entre memória individual e memória coletiva. De acordo com Pollak, a memória é algo herdado e não se refere apenas a um indivíduo. Ela está passível de sofrer mudanças de acordo com as preocupações pessoais e políticas do momento (1992, p. 4). No caso de profissões intelectuais como o jornalismo é recorrente a confusão entre a memória individual e a memória nacional. Assim sendo, é plausível considerar as biografias e memórias de jornalistas como fontes importantes para uma pesquisa que se concentra nas transformações ocorridas na produção cultural transcorridas nas últimas três décadas e que recaíram diretamente sobre o jornalismo. Entretanto, qual tratamento dar às biografias e memórias? Para responder a essa questão faz-se necessário, antes, situar a biografia dentro do campo disciplinar da história e, na sequência, lançar mão de um exemplo para ilustrar sua condição, nesse caso, as biografias e memórias de jornalistas.

A disciplina histórica atravessou várias fases de revisionismo. A mais profícua se deu com a revolução documental, pois contestou a norma segundo a qual o documento histórico seria essencialmente um texto escrito e autêntico. Pode-se inferir que a ampliação na noção de documento histórico foi concomitante a uma ampliação temática. Nesse sentido, abordar memórias, 
relatos biográficos, arquivos pessoais como fontes históricas retoma algumas transformações ocorridas na forma de lidar com os documentos e as questões históricas. Le Goff argumenta que o documento escrito foi para a escola histórica positivista entre o fim do século XIX e início do século XX, o fundamento do fato histórico, isto é, ainda que resultasse da decisão do historiador este era considerado por si mesmo como uma prova histórica (LE GOFF, 2003, p. 537). A aproximação com a lógica das Ciências Naturais consistiu também em acreditar que a História era uma ciência de observação. Tal assertiva remonta à chamada escola metódica cujo principal legado, além de formular as diretrizes deontológicas da profissão, foi estabelecer a crítica como a base fundamental do ofício. Para precursores como Langlois e Seignobos, não pode haver história sem crítica uma vez que esta se refere ao passado e também um conhecimento a partir de vestígios. Em função disso, um fato histórico é o resultado de um raciocínio a partir de vestígios, segundo as regras críticas (PROST, 2008, p. 67). Entretanto, como adverte Prost, a ingenuidade da escola metódica do final do século XIX foi empreender o encadeamento simples entre documento, crítica e fato (2008, p. 70). Agindo dessa forma esses historiadores negligenciaram a importância do questionamento e também a interdependência entre fatos, documentos e questões. Os fundadores da escola do Annales alertaram que a história não pode proceder a partir de fatos uma vez que não há fatos sem questões. Existe um primado do questionamento sobre os fatos e este é parte decisiva na construção da história tal como preconiza Prost:

Com efeito, o campo da história não pode definir-se por seu objeto, nem por documentos. Com vimos, não existem fatos históricos por natureza; além disso, o campo dos objetos, potencialmente históricos é ilimitado. É possível fazer - e faz-se - história de tudo (...) pela questão é que se constrói o objeto histórico, ao proceder a um recorte original no universo ilimitado dos fatos e documentos possíveis (PROST, 2008, p. 75). 
Assim, é o questionamento a ser feito às biografias e memórias que confere peso histórico à fonte de pesquisa. A revolução documental promovida pela escola dos Annales foi responsável pela ampliação da noção de documento que passou a não se restringir ao arquivo e ao texto escrito. Tem-se que esta ampliação da noção de documento foi acompanhada por uma ampliação temática a partir da década de 1960. Desse modo, o interesse da memória e da história coletiva passou igualmente a não se limitar aos grandes personagens e acontecimentos, mas abarcar a história de todos os homens incluindo os marginalizados, excluídos e anônimos o que suscitou uma nova hierarquia dos documentos (LE GOFF, 2003, p. 541).

Outro fator importante para se compreender a crítica documental é a diferenciação entre fonte e documento. Os documentos dependem dos historiadores para se tornarem fontes. Os historiadores inventam suas fontes e por isso pode-se dizer que não existem documentos que sejam privilegiados (LARA, 2008 , p. 18). A própria leitura dos textos produzidos na História não deve buscar apenas o que foi escrito, mas como foi escrito, por que foi, o modo pelo qual o texto circulou e foi produzido, bem como o contexto de sua produção. Ao se debruçar sobre as fontes textuais e sua estrutura retórica, Lara chamou atenção ao processo de transformação do texto em fonte histórica. Segundo a pesquisadora, todo formato de texto pode ser transformado em fonte histórica basta que se reconheça nele os eventos descritos, os procedimentos narrativos adotados, a forma de circulação do original e como pode ser lido no seu contexto (LARA, 2008, p. 32).

Pensar a crítica documental é também reconhecer que o status de um documento tem a ver com a época em que se processa a análise sobre ele e, acima de tudo, reconhecer que o documento é perpassado por seguidas etapas de reconstrução. Os avanços teóricos dos precursores da Nova História tiveram como desdobramentos a mudança no estatuto epistemológico da verdade, 
bem como o esgarçamento da noção de documento. Este passou a ser tudo aquilo que em um determinado momento decidiu-se que é documento. É o olhar do presente que atribui peso e importância histórica ao documento. Isso significa que um documento histórico é considerado como tal em função de uma determinada visão de época, pois somente existe em relação ao meio social que o preservou. Dessa forma, o valor do documento para o historiador somente é obtido a partir da teia social que o envolve e pelo que revela de mais amplo de uma época e uma sociedade (KARNAL; TATSCH, 2009, p. 21).

No que concerne à historiografia da imprensa era comum até a época em que Realidade circulava como publicação mensal cultuada da Editora Abril que a história do país documentada em jornais e revistas estivesse de certa forma atrelada à história de suas testemunhas oculares, os repórteres. A linguagem jornalística padronizada ainda não havia sido adotada em veículos de periodicidade estendida e por isso, em Realidade, várias reportagens vinham registradas com a marca autoral. Era recorrente o emprego de recursos literários como a primeira pessoa do singular e figuras de linguagem. A revista chegou a veicular o gênero reportagem-conto que consistia em matérias em que um personagem real era escolhido para protagonizar determinado assunto, mostrando a dimensão épica da vida de pessoas comuns por meio de recursos literários. Entretanto, a partir de momento em que a atividade jornalística tornou-se mais técnica e menos autodidata a reportagem literária migrou para os livros reportagem e para revistas cada vez mais especializadas como, por exemplo, a atual revista Piauí. Realidade diferentemente de Piauí funcionava como uma revista de informação geral tal como as revistas semanais atuais e suas contemporâneas como a Manchete e Fatos e Fotos. Nesse quesito residia o diferencial da revista Realidade. Dessa forma, a mudança no mercado profissional e a própria conjuntura fizeram muitos desses profissionais migrarem para a Imprensa Alternativa durante a década de 1970. Entre os entrevistados para essa pesquisa, muitos ainda 
participam de projetos alternativos; além disso, publicam livros de grandes reportagens e obras sobre suas memórias profissionais. A fim de realizar uma análise sobre as obras publicadas por esses remanescentes faz-se necessário abordá-las sobre a perspectiva da história.

O uso de material jornalístico para produção historiográfica e a preocupação em escrever uma história da imprensa não são recentes. Acrescenta-se que atualmente os periódicos compartilham com outros objetos até mesmo uma condição de centralidade na produção do saber histórico. Contudo, durante algum tempo imperou entre os historiadores uma relutância com relação à ideia de mobilizar jornais, revistas, gravações de programas jornalísticos em áudio e vídeo para a escrita da história por meio da imprensa como destaca Regina de Luca (2010, p. 111). De acordo com a historiadora, esta resistência inicial se deve ao fato de que durante o século XIX e início do século XX o ideal de busca da verdade por meio dos registros estava cristalizada na História bem como a hierarquia qualitativa dos documentos. Nessa ordem os jornais eram considerados pouco adequados, em primeiro lugar por serem registros fragmentários do presente e em segundo lugar por serem realizados sob a influência de conflitos de interesses e paixões e, sendo assim, "em vez de permitirem captar o ocorrido, dele forneciam imagens parciais, distorcidas e subjetivas" (LUCA, 2010, p. 112). Posteriormente, a partir da segunda metade do século XX, com os desdobramentos das contribuições analíticas da História Nova e terceira geração da Escola dos Annales se propôs uma renovação em termos de objetos, problemas e abordagens. As inovações teóricas não tardaram a repercutir no Brasil e já em 1970 o estatuto da imprensa como objeto sofreu um deslocamento fundamental, isto é, ao lado da História da imprensa e por meio da imprensa, o próprio jornal tornou-se objeto da pesquisa histórica (LUCA, 2010, p. 118). Nesse sentido, é possível salientar que os registros da atividade da imprensa são importantes não exatamente por serem "retrato" de uma época, mas porque funcionam como 
amplificadores da relação estabelecida entre os meios de comunicação e a sociedade. Por meio de periódicos antigos pode-se investigar, por exemplo, como a hierarquia de um jornal se associa e se mantém por meio dos vínculos que cultiva com as elites intelectuais, políticas e econômicas.

Observar o registro histórico sem considerá-lo reprodução fiel dos fatos passados remonta a uma perspectiva que interessa quando o assunto em questão são os relatos autobiográficos. Testemunhos de histórias de vida não compreendem a totalidade da vida de um indivíduo, eles são uma seleção de fatos significativos feita por quem conta uma história sob o próprio ponto de vista. Esta perspectiva busca comunicar uma identidade coerente consigo mesma. Cabe recordar aqui a função exercida pelo "nome próprio" que unifica e confere uma coerência ao histórico individual, indiferente aos distintos posicionamentos deste indivíduo em determinado campo e as mutações dentro dele (BOURDIEU 1996, p. 77). 0 mosaico de acontecimentos formado por uma biografia pode fornecer indícios sobre a interação entre os sujeitos e os distintos âmbitos (familiar, profissional, social) em que circularam. Em outras palavras, nas biografias não encontramos a reprodução fiel da história, mas a forma com que foi apreendida pelos biografados e por aqueles que realizaram as narrativas sobre si. Dessa maneira, quando um amigo biografa outro com a autoridade de um companheiro de viagem, falando em nome de uma geração, temos aí uma consonância de narrativas: a do biógrafo, do biografado e do grupo. A coerência deixa entrever a "voz do grupo" que reivindica sua história e as incongruências descortinam possíveis conflitos internos e externos desse grupo.

Os relatos autobiográficos podem ainda estar integrados aos arquivos institucionais ou pessoais na forma de testemunhos e também podem fornecer subsídios para produção de memórias e biografias. No entanto, é necessária uma postura crítica na leitura de ambos tipos de fontes. É pertinente retomar os movi- 
mentos feitos por pensadores e teóricos na tentativa de contestar o primado da objetividade nos registros históricos.

Le Goff destacou que a história é a forma científica da memória coletiva. Para ele, os materiais da memória podem se apresentar sob duas formas principais: os monumentos, que são heranças do passado; e os documentos, que são uma escolha do historiador, levando em consideração os limites do arquivo, do que resta, do que foi alvo de investimento ou preservação. 0 historiador descreve o triunfo do documento sob o monumento ao longo do século XVIII. Também discorre sobre o modo como os historiadores do século XIX, imbuídos pelo espírito positivista, alçaram os documentos textuais à condição de prova fidedigna de fatos do passado em detrimento dos monumentos. Como a objetividade do documento afirmava-se essencialmente no documento textual foi preciso empreender uma busca pela objetividade e contrastar os vários registros. Havia, entretanto, um prenúncio de uma crítica ao documento. Porém, era a procura pela autenticidade que ainda movia os historiadores do século XIX. Posteriormente, nas primeiras décadas do século XX, os fundadores da revista Annales d'histories économiques et sociale (1929) tornaram-se pioneiros de uma nova história ao argumentarem que a noção de documento deveria ser alargada para além dos arquivos institucionais. A chamada revolução documental empreendida prosseguiu em um movimento crescente até a década de 1960 quando alguns estudiosos anunciaram que o interesse da memória coletiva e da história já não era apenas os grandes homens e os grandes acontecimentos, mas fatos corriqueiros e de todos os homens. Entretanto, Le Goff advertiu que o procedimento de monumentalização dos documentos persistia como um risco que o historiador não poderia negligenciar. Propôs, assim, radicalizar a crítica ao documento.

O documento não é inócuo. É antes de mais nada o resultado de uma montagem, consciente ou inconsciente, da história, da época, da sociedade que o produziram, mas também das 
épocas sucessivas durante as quais continuou a viver, talvez esquecido, durante as quais continuou a ser manipulado, ainda que pelo silêncio. 0 documento é uma coisa que fica, que dura, e o testemunho, o ensinamento que ele traz devem ser em primeiro lugar analisados desmistificando-lhe o seu significado aparente. 0 documento é monumento. Resultado do esforço das sociedades históricas para impor ao futuro determinada imagem de si próprias (LE GOFF, 1992, p. 548).

As ponderações sobre a escrita da história ressoaram na reorientação a respeito do documento. De Certeau, estudioso que dedicou várias linhas à investigação do homem ordinário, observou que a história era resultado da transmutação de coisas ordinárias do mundo em documentos. Para ele, "em história tudo começa com o gesto de separar, de reunir, de transformar em "documentos" certos objetos distribuídos de outra forma" (DE CERTEAU, 2010, p. 81). Esta nova distribuição é um processo cultural e carrega em si a marca do lugar social do qual precede o historiador ou quem empreende a escrita da história. A escrita da história está por certo marcada por sua procedência e os testemunhos são parte vital do trabalho historiográfico. Para Ricoeur tudo começa com o testemunho, "com o testemunho inaugura-se um processo epistemológico que parte da memória declarada, passa pelo arquivo e pelos documentos e termina na prova documental" (RICOEUR, 2007, p. 170). Esse pensador registra que o ato de fazer história é inaugurado quando se assume em primeiro plano a iniciativa de pessoa física ou jurídica que visa preservar os rastros de sua própria atividade. Aqui, o arquivo promove a ruptura com o ouvir dizer do testemunho oral (RICOUER, 2007, p. 178).

A temática do testemunho orientou o estudo de Marc Bloch. Esse historiador investiu na fundação de uma nova forma de enxergar a história através de uma postura crítica diante dos documentos e dos testemunhos. Ao contestar a objetividade do conhecimento histórico argumentou que era impossível descrever com imparcialidade os fatos passados. Pois o conhecimento 
do passado é mediado por testemunhas sendo assim um conhecimento indireto. 0 estudioso aferiu que o conhecimento do passado pelos historiadores é adquirido através de vestígios, ao contrário da observação direta posta em prática no domínio das ciências naturais. Para ele: O passado é por definição um dado que nada mais modificará. Mas o conhecimento do passado é uma coisa em processo, que incessantemente se transforma e se aperfeiçoa (2001, p. 75). Bloch empreendeu uma crítica às provas materiais e, especialmente, ao testemunho. Para ele, o uso de testemunhos diversos e opostos é uma especificidade da história, o que se justifica, já que os fatos humanos são complexos. Adverte que os testemunhos devem ser avaliados através das técnicas de pesquisa e, sobretudo, pela sensibilidade do historiador, já que na crítica ao testemunho todos os dados estão viciados, pois elementos muito delicados intervêm constantemente para fazer a balança pender para uma eventualidade privilegiada (BLOCH, 2001, p. 118).

Os testemunhos advêm das memórias e estas não escapam à necessidade de uma percepção criteriosa, pois o passado é impossível de ser apreendido em sua integralidade. Pollak foi um historiador que se debruçou sobre a relação entre a memória e os processos de construção e manutenção da identidade coletiva. Para ele, a memória é seletiva porque nem tudo fica registrado. Isto é, a organização da memória se dá em função das preocupações pessoais e políticas do momento. Ela sofre flutuações em função do momento em que é articulada, em que está sendo expressa. 0 que a memória individual grava, concentra ou exclui é resultado de um trabalho de organização. 0 historiador ressalta que a memória é um fenômeno construído social e individualmente. Em se tratando da memória herdada ou coletiva, há uma ligação muito estreita entre a memória e o sentimento de identidade individual ou coletiva, sendo, também, um elemento importante do sentimento de continuidade e coerência de uma pessoa ou de um grupo em sua construção de si (POLLAK, 1992, p. 5). Pollak sublinha que memória e identidade estão presentes 
em conflitos intergrupais diversos. Em função das disputas para o estabelecimento e manutenção da memória e identidade coletivas há esforços constantes os quais classifica como trabalhos de enquadramento da memória.

0 trabalho de enquadramento da memória se alimenta do material fornecido pela história. Esse material pode sem dúvida ser interpretado e combinado a um sem-número de referências associadas; guiado pela preocupação não apenas de manter as fronteiras sociais, mas também de modificá-las, esse trabalho reinterpreta incessantemente $o$ passado em função dos combates do presente e do futuro (POLLAK, 1989, p. 3).

As considerações dos historiadores acima demonstram que documento histórico, testemunhos e memória são passíveis de construção de acordo com as circunstâncias, o contexto e a subjetividade de quem profere ou redige os testemunhos. É de suma importância destacar que a produção da memória muda com as transformações no contexto posto que esta produção memorialística toma parte do devir. Tais contingências incidem sobre a própria escrita da história e isto vale para a escrita acadêmica e para a escrita autobiográfica.

As contingências da produção da memória estão implícitas nas características das obras biográficas e memorialísticas dos precursores da revista Realidade. 0 olhar retrospectivo do jornalista que conta sua história é capaz de demonstrar assim o entrelaçamento entre memória individual e memória coletiva o que evidencia a remissão à identidade tradicional jornalística, isto é, a identidade consagrada a qual as obras em questão reverenciam e reproduzem o padrão de consagração. Cabe então identificar e exemplificar as características dessas obras.

Os livros que tratam das memórias e biografias, assim como os relatos biográficos obtidos em entrevistas, apresentam uma 
perspectiva de fusão entre vida pessoal, profissional e do grupo formado em Realidade e que prosseguiu relativamente unido durante o período da Imprensa Alternativa. As obras que se enquadram dentro dessa perspectiva são Jornalistas: 1937 a 1997 de José Hamilton Ribeiro; Realidade - a revista que virou lenda de Mylton Severiano; Eu é um outro de Roberto Freire; Realidade Re-vista de José Carlos Marão e José Hamilton Ribeiro; e Cicatriz de Reportagem - 13 histórias que fizeram um repórter de Carlos Azevedo. 0 autor da última obra citada comenta em seu livro sobre o prestígio conquistado pela revista:

No início de 1967, Realidade era um sucesso de público, respeitada e também polêmica nos meios de imprensa. Até despertava manifestações de despeito. Mandávamos nossas matérias para concorrer ao Prêmio Esso. Mas, salvo engano, em nosso período, a revista não levou nenhuma vez o prêmio principal. Alguém disse, e não sei se aconteceu mesmo, que certa vez a comissão julgadora do Prêmio Esso considerou que as matérias de Realidade eram hors concours, tão boas que seria até injusto concorrer (AZEVEDO, 2007, p. 217).

A notoriedade da publicação é reiterada por Azevedo nesse trecho bem como a noção da importância do grupo do qual fazia parte. No livro citado o jornalista descreve o processo de produção de reportagens que marcaram sua carreira, o número de reportagens publicadas na revista, cinco ao todo, é significativamente superior se relacionado aos outros meios em que foram publicadas as matérias escolhidas como representativas de sua carreira. Além disso, na referida obra, o autor dedica vários capítulos a contar a história da equipe e do processo de ascensão e declínio da revista Realidade.

A referência à força de coesão e sintonia do grupo foi mencionada nas entrevistas concedidas e também nas memórias e relatos biográficos. Nesses relatos a história da revista e do grupo é indissociável muitas vezes da história individual. 0 livro de 
Mylton Severiano é demonstrativo dessa característica. Em $R e$ alidade - a revista que virou lenda o fio condutor dos capítulos é a trajetória do grupo e das pessoas que estavam nos bastidores da revista enquanto essa conquistava alcance nacional. Mylton entrevistou seus colegas e teve acesso aos arquivos dos que já haviam falecido. Na redação do livro sobre a revista Realidade lançou luz sobre produtores da publicação contando suas origens, formação intelectual, laços familiares, sociais e profissionais. No prólogo da obra o leitor se depara com uma comparação que pode soar exagerada, mas que faz sentido em relação à narrativa da história desses amigos e profissionais:

Assim foi com Realidade. Éramos bons, do redator-chefe ao office-boy, do dono a seu filho. Separados, teríamos trabalhado direito. Juntos, fizemos história. Eis a questão: o que acontece com os Beatles, Realidade e todo o trabalho que vira cult? Espírito de colmeia. Entrevistados meus cravaram: nós amávamos o que fazíamos - captar o real e passar adiante, ensinando, comovendo e divertindo as pessoas, como as abelhas amam captar néctar e fazer meu. 0 que marca a fundamental diferença, então, é que nós também nos amávamos. E que amor tínhamos pelo povo brasileiro (SEVERIANO, 2013, p. 9).

Mylton enfatiza de forma romantizada a relação entre o sucesso alcançado por Realidade e a sintonia entre os integrantes do grupo. Desconheço os conflitos internos ocorridos entre os entrevistados durante ou depois do período de Realidade, mas posso inferir que a referência à convergência de talentos pode ter sido uma forma de repensar e tentar explicar para si mesmo e para a profusão de pesquisadores os motivos que levaram aquela publicação ter se tornado um dos marcos na história da imprensa brasileira, ao menos, no âmbito intelectual e acadêmico.

Outra característica dos relatos memorialísticos dos profissionais consiste na fusão entre as histórias pessoal, profissional e do país. A referência ao declínio da revista diante da escalada do 
golpe militar e da censura tiveram repercussão direta na vida pessoal e profissional desses jornalistas, pois os empurraram para a imprensa alternativa ou até mesmo para a clandestinidade. 0 momento de efervescência cultural e política da década de 1960 é também sempre rememorizado como "gatilho" para aquela forma de expressão jornalística que gerou Realidade. É o caso de Carlos Azevedo que assim menciona o período de aglutinação de jornalistas para formação da equipe:

Era um momento raro de ebulição, em que antigos modelos e preconceitos explodiam e se desmanchavam à nossa volta, em que as feministas anunciavam um novo protagonismo da mulher. Urgia ler Lênin e Sartre para tentar entender o que parecia ser o começo de uma nova época na História, mas ao que parece, era o fim (...) Vietña e o maio de 1968 na França vinham de cambulhada com a discussão sobre Freud, Erich Fromm, "Summerhill", a escolas da liberdade de A. S. Neill; Herbert Marcuse. E no Brasil, havia uma ditadura militar recém-instalada, que já silenciara o movimento sindical e camponês, mas ainda estava na véspera de cometer seus piores crimes. Enfim, era uma turma que não tinha tempo a perder, sentia a urgência de participar daquele mundo em transformação, que, achávamos, seria dos jovens e nunca mais seria o mesmo, que haveria de ser melhor, de mais igualdade, e aí morava o nosso engano (...) Viemos por caminhos diversos até Realidade, e essa riqueza de experiências resultou num produto surpreendente, maior que todos (AZEVEDO, 2007, p. 105).

A narrativa de Azevedo tem em comum com a de Severiano a designação do pronome "nós" para referir-se à revista Realidade. Nesses relatos se dá ênfase à ideia de que a revista e o grupo são indistintos e por serem tratados como uma coisa só ao se reiterar o prestígio da publicação se consagra tanto o grupo, como o profissional que narra suas experiências após quatro décadas transcorridas, período em que o mito em torno da revista Realidade foi sendo paulatinamente construído. Dessa maneira, posso inferir que há uma confluência e até mesmo uma identificação entre memória individual e memória coletiva. 
Ao promover o diálogo entre os historiadores e o meu objeto atual de estudo, os jornalistas intelectuais, tenho condições para lançar mão de algumas questões que podem orientar a pesquisa. Se a edificação e manutenção da memória coletiva é alvo de conflitos e está sujeita a sofrer processos de enquadramento em momentos de mudança, quais foram as circunstâncias da produção das biografias tomadas como exemplo? Assim, é preciso considerar o momento de mudança que atravessa o jornalismo e sua relação com as biografias coletivas. Qual seria o ponto de vista do jornalista escritor ao redigir um livro de memória, o do intelectual ou o do profissional de imprensa? Quais seriam as condições gerais de produção dessas biografias e memória? Tais questionamentos têm maiores chances de serem solucionados se equacionados com os resultados da pesquisa de campo? As entrevistas são fontes distintas e por isso merecem outra forma de tratamento. No entanto, são cruciais para se compreender as imbricações entre as mudanças no campo jornalístico e os recentes lançamentos de memórias e biografias de jornalistas.

\section{U m campo profissional em mutação}

O estudo dos livros biográficos como documentos históricos exige uma investigação sobre os princípios de produção dessas fontes. Relatos autobiográficos colhidos por meio de entrevistas, ainda que fontes distintas, também requerem uma análise sobre o contexto em que foram proferidos. Ao coligir o conteúdo das fontes e promover o diálogo com as trajetórias dos jornalistas intelectuais em questão, é possível inferir os princípios de produção das referidas narrativas de histórias de vida.

As condições de produção dos livros de memórias evidenciam um contexto de intensas transformações no campo jornalístico. Tem-se que o profissional de imprensa se modificou da segunda metade do século XX aos dias atuais. A figura do jornalista romântico atravessou um longo processo de profissionalização até 
ser substituída pela imagem do burocrata produtor de notícias. A industrialização dos meios de comunicação e a profissionalização do jornalista são pontos de referência de um momento em que a atividade abandona o autodidatismo original e sua ancoragem na literatura.

Vários fatores contribuíram para essa transformação: a grande reforma gráfica e editorial nos jornais, a partir da década de 1950; o momento de modernização e industrialização que vivia o país no período, o que deu propulsão às mudanças na forma e no conteúdo dos jornais (BAHIA, 1990, p. 379); a elaboração dos manuais de redação que padronizaram a linguagem jornalística e seu modus operandi; a exigência do diploma de graduação em jornalismo para o exercício da profissão, a partir do Decreto-Lei no 972, de 17 de outubro de 1969 (vigente até 2009); e, na década de 1990 e primeira década dos anos 2000, a crescente simbiose entre as novas tecnologias de informação e comunicação e a própria essência da atividade.

As mudanças no campo jornalístico tiveram ressonância nas formas de autorrepresentação do jornalista. A partir de 1950 é possível inferir que se deu o início do processo de autonomização do campo jornalístico em relação ao campo literário, fundamental para a autoconstrução da legitimidade da própria profissão. Tais reformas podem ser vistas, pelos próprios profissionais, como o momento de construção do marco fundador de um jornalismo que se fazia moderno e permeado por uma neutralidade fundamental para espelhar o mundo (BARBOSA, 2007, p. 150). Isso significa que a figura clássica do jornalista aspirante a escritor que conjugava o trabalho na imprensa e o engajamento político foi substituída pela imagem do profissional cuja atividade é calcada na técnica e nas ferramentas tecnológicas que utiliza para exercer sua função. A imagem romântica muito proeminente até a década de 1970, momento de explosão da Imprensa Alternativa - em que se destacaram jornais como $O$ Pasquim, Ex e Movimento -, ainda estava muito associada à ideia 
do jornalista, escritor e intelectual. Deduzo que esta é a imagem que coincide com a imagem clássica que se reflete em figuras como Machado de Assis, Lima Barreto, João do Rio, Antônio Calado, entre outros, que conquistaram o reconhecimento como jornalistas intelectuais.

A tecnicização da profissão e a exigência do diploma propiciaram o aparecimento de um conflito entre "antigos" e "novos" jornalistas nas décadas de 1980 e 1990. Os "antigos" jornalistas são aqueles que tiveram formação autodidata e definiram suas identidades profissionais em um momento histórico de enfrentamento do poder político e econômico e se caracterizam pela "postura crítica". Os "novos" jornalistas são os egressos de cursos superiores de jornalismo, considerados pelos mais experientes como alienados, desprovidos de vivência e de crítica. Trata-se do conflito entre dois capitais simbólicos distintos, de um lado o capital tradicional pautado pela trajetória profissional como sinônimo de vivência e o outro capital representado pela formação universitária (BERGAMO, 2011, p. 252). A defesa do autodidatismo em contraposição à titulação escolar para admissão e formação profissional aparece escamoteada na defesa de Mylton Severiano da inata vocação ao jornalismo:

Todos gostavam de ler. Eram autodidatas. Graças a Deus não havia a exigência do diploma. A revista não seria possível. Hamilton Almeida Filho, por exemplo, um dos melhores repórteres que eu já vi na minha vida, começou a trabalhar ao quinze anos, no jornal carioca A noite, hoje extinto. Se houvesse a exigência do diploma, como um cara como esse faria? (...) Jornalista é vocação, é como ser pintor, escritor, poeta... Como você pode pedir a um poeta: deixe-me ver seu diploma de poeta? (MORAES, 2010, p. 144)

Há no comentário de Severiano explicitação de uma ideia de aproximação entre jornalismo e as atividades artística e literária. Outras expressões do imaginário jornalístico são correla- 
tas como "faro" jornalístico, para designar que um profissional sabe instintivamente o que é notícia. Mas a imagem do jornalista como um escritor em potencial é uma referência a um modelo consagrado pela historiografia da imprensa a qual os memorialistas em questão miram quando redigem ou proferem relatos sobre si mesmos e seu grupo.

Contudo, apesar da ênfase dada à formação intelectual autônoma, alguns já haviam passado pelos bancos universitários, Roberto Freire era formado em medicina; Paulo Patarra, José Hamilton Riberio e Frei Betto haviam passado pelo curso de jornalismo sem que o concluíssem; o próprio Mylton Severiano havia cursado seis anos do curso de música em conservatório e também havia cursado dois anos de Direito tendo ao final optado pelo jornalismo. Destaca-se ainda que a contraposição em relação à exigência do diploma para o exercício da profissão foi expressa por vários dos entrevistados, mas não foi unânime. 0 jornalista Carlos Azevedo embora não concorde com o curso de jornalismo como condição obrigatória para o exercício da profissão acredita ser necessário um curso universitário que dê recursos intelectuais para os aspirantes ao jornalismo. José Carlos Marão também se posicionou em prol do diploma, assim como José Hamilton, com quem escreveu Realidade Re-vista. Ribeiro é inclusive autor de Jornalistas 1937 e 1997, livro que celebrou o aniversário de 60 anos do sindicado dos jornalistas paulistas. Segundo o jornalista, o sindicato, investiu e incentivou a criação de cursos superiores de jornalismo (Ribeiro, 1998, p. 13). José Hamilton faz a defesa dos cursos de jornalismo no Brasil:

O Brasil é um país semi-alfabetizado e historicamente retardatário - as coisas acontecem aqui muito tempo depois de serem novidade na Europa, nos Estado Unidos e até em nossos vizinhos. 0 Peru teve universidade anos-luz à frente de nós. Enquanto for assim, é bom para o país que jornalista tenha curso superior, para que seja mais confiante e crítico do que faz. A universidade, ruim que seja, amplia o horizon- 
te de um jovem que vai ser jornalista. É melhor jornalista com diploma do que a situação anterior em que as empresas recrutavam analfabetos para a redação e lhes pagavam com um prato de comida. No livro "Jornalistas 37/97" sobre o Sindicato dos Jornalistas de S. Paulo, há uma afirmação de que, entre os associados, havia 19 analfabetos. De um deles o livro traz até uma entrevista (entrevista concedida por correio eletrônico).

É possível inferir então que a rejeição de alguns dos entrevistados não seja ao título escolar, mas ao diploma de jornalismo em específico. Tal aferição pode remeter o posicionamento a dois contextos distintos. Em primeiro lugar, evidencia a oposição em relação à decisão do governo autoritário em colocar mais esse obstáculo ao livre exercício da profissão no final da década de 1960; e em segundo lugar, aponta o conflito por cargos de chefia e altas posições na hierarquia profissional entre a geração formada no interior das redações e a geração formada nas universidades, esse ocorrido posteriormente, já nas décadas de 1980 e 1990.

\section{A autoria no jornalismo}

A celeuma entre os "jornalistas por vocação" e os "jornalistas por profissão" é um sintoma das transformações ocorridas no campo jornalístico. Tais mudanças tiveram repercussões significativas relacionadas à linguagem, à autoria e à identidade jornalística. A implantação dos manuais de redação e estilo ajudou a fundar uma linguagem específica e destacada da expressão literária. Mas a autonomia relativa conquistada não destituiu ao todo o jornalismo de sua função de autor. A partir da distinção entre os gêneros textuais da notícia e da reportagem é possível evidenciar as mudanças na questão autoral. De acordo com os manuais de redação recentes foi estabelecido que a notícia trás a informação concisa, informativa e destituída da assinatura; já a reportagem caracteriza-se pelo texto denso, resultado de pesquisas extensas e carrega a assinatura de seu autor. A notícia 
pode vir assinada coletivamente com a expressão "da redação" ou mesmo assinada por um jornalista individualmente. No entanto, a designação dessa autoria está mais associada à propriedade intelectual do que ao prestígio profissional ou ao exercício da crítica ou liberdade de expressão. A notícia é produto das rotinas de trabalho das redações e, embora possa explicitar o nome do autor, é destituída de marcas autorais. Em contrapartida, a reportagem é o gênero icônico da profissão, pois traduz o capital simbólico peculiar ao jornalismo relacionado à trajetória e a vivência pessoal-profissional. Em outras palavras, poderia-se dizer que a notícia informativa está para o jornalismo técnico, assim como a reportagem está para a versão tradicional da profissão. A reportagem é também aquela que compõe o registro oficial da história da imprensa e entrelaça a experiência pessoal do autor à história coletiva. Segundo Bergamo, a distinção entre reportagem e notícia revela a hierarquização vinculada à crescente divisão do trabalho de escrita e de registro. Para o sociólogo, a "desigualdade estrutural entre reportagem e notícia" ocasiona implicações na identidade jornalística e, sobretudo, no registro memorial profissional.

O texto noticioso é feito para ser lido uma única vez. Já a reportagem - narrativa e autoral - deve ser não apenas lida, mas, no caso de algumas delas, deve ser relida. A "memória do jornalismo" é composta justamente daqueles textos que, dada sua importância para a profissão, devem ser "re-lidos" e servir de modelo para as novas gerações. São textos que têm a dupla função tanto de informar como de formar sobre o passado, "a história". Com isso, a desigualdade presente nas "memórias da profissão" reproduz a própria desigualdade estrutural entre seus profissionais e seus textos, entre a autoria e a não autoria, e consequentemente, entre os diferentes "valores documentais" que lhe são atribuídos (BERGAMO, 2014, p. 226).

Nesse sentido, é importante situar o jornalismo dentro do cenário mais amplo das transformações na produção cultural e 
recordar algumas das apreciações de Foucault a respeito da autoria. De acordo com esse pensador, na epopeia grega, a narrativa tinha o dever de conferir imortalidade ao herói. Por sua vez, na cultura ocidental moderna, a obra passou a "ter o direito de matar, de ser assassina do seu autor". Com isso Foucault quer dizer que a consolidação do nome do autor e sua obra obliteram o sujeito autor ou as características individuais do sujeito que escreve em nome da consagração da obra, e sendo assim, $a$ marca do escritor não é mais do que a singularidade da sua ausência: é-lhe necessário representar o papel do morto no jogo da escrita (FOUCAULT, 2009, p. 55). 0 filósofo francês ainda destaca que em nossa cultura alguns textos são providos da função de autor enquanto outros não são. Se observarmos as transformações ocorridas no jornalismo com relação à linguagem pode-se perceber que a função da autoria por excelência está destinada a apenas poucos nomes consagrados dentro da profissão. Mas como as questões associadas à autoria e à linguagem se relacionam às outras atividades da produção cultural e suas transformações? Para responder a essa indagação é necessário examinar o processo que deu autonomia relativa às funções de intelectual, artista e jornalista nas últimas décadas.

A partir da década de 1970 ocorre um processo de profissionalização e segmentação de áreas atreladas à produção cultural. Espaços profissionais específicos são abertos para as atividades políticas e culturais no Brasil. Vários fatores vão convergir: o estabelecimento de uma indústria cultural com desenvolvimento da televisão, da indústria fonográfica, cinematográfica e editorial; a influência do processo gradativo de redemocratização que reintegrou os indivíduos em atividades políticas oficializadas; a criação de instituições estatais de apoio e financiamento à produção artística, bem como o desenvolvimento de um sistema nacional de pós-graduação e apoio à pesquisa, com a consequente transformação da Universidade em espaço autônomo, instituindo formas de inserção profissional para os intelectuais de carreira (PEREIRA, 2008, p. 223). Ocorreu uma transformação no 
universo das produções culturais que foi contemporânea à entrada ou retorno de muitos jornalistas às universidades e em cursos de pós-graduação como pesquisadores e/ou docentes.

Com a abertura de espaço nas universidades é possível observar que aumentou a produção de trabalhos científicos e obras memorialísticas a respeito da história da imprensa. No conjunto de trabalhos, a revista Realidade ocupa um lugar privilegiado, sendo aclamada como um marco na história da imprensa brasileira. 0 aumento no número de trabalhos científicos que abordam os prestigiados veículos e jornalistas - utilizando-se do método da história oral - foi seguido pela publicação de biografias individuais e coletivas. É curioso que o registro da memória dos chamados "casos exemplares" da história da imprensa nacional - sejam eles jornais, revistas ou indivíduos - tenham sido resgatados no ambiente cultivado nas universidades a partir das décadas de 1970 e 1980, justamente no momento em que vigorava maior censura aos meios de comunicação e que a produção científica ganhava fôlego e incentivo profissionalizante.

Entre os trabalhos científicos sobre a história da imprensa alguns surgiram da própria experiência jornalística. Kucinski, autor de Jornalistas e Revolucionários, foi levado a citar-se em terceira pessoa ao realizar um levantamento sobre os jornais e protagonistas da Imprensa Alternativa na qual atuou como jornalista. 0 próprio arquivo pessoal do pesquisador talvez tenha sido incorporado à pesquisa. Sendo assim, seria possível conjecturar qual seria a relação entre os arquivos pessoais que se tornaram biografias e aqueles que resultaram em trabalhos científicos. Deduzo que o que os relaciona são as intenções subjacentes ao processo de arquivamento e utilização desse arquivo para algum fim posterior, ainda que estes objetivos sejam distintos. Heymann, pesquisadora que se dedicou ao estudo do arquivo pessoal de Darcy Ribeiro, direcionou sua análise à captação dos aspectos relacionados à construção do legado memorial e dos diferentes caminhos e agentes envolvidos na fabricação do 
arquivo do citado intelectual e político brasileiro. As reflexões da pesquisadora podem contribuir para nossa reflexão no sentido de perceber nos arquivos pessoais algo além de textos que carregam testemunhos. É necessário enxergá-los como documentos que podem ser empregados posteriormente na produção de biografias ou trabalhos científicos. Assim como pode ocorrer em arquivos públicos, muitos agentes e muitas variáveis interferem na produção dos conjuntos documentais de natureza pessoal (HEYMANN, 2012, p. 49), isto é, há razões para o arquivamento e para a utilização posterior. Tais razões podem estar ligadas ao legado que os indivíduos pretendem imprimir na história.

O conjunto de intenções profissionais e pessoais que pesam na constituição de um arquivo pessoal capaz de tornar-se uma obra de pesquisa acadêmica ou memorialística sobre a história da imprensa e de quem fez a imprensa está também de certa forma relacionada à questão da autoria. Tendo em vista que o moderno jornalismo concede outro tratamento à autoria, posso inferir que os jornalistas remanescentes de Realidade que se dedicaram a redigir suas memórias mirando em um modelo tradicional e prestigiado de autor no jornalismo. As biografias e memórias fazem referência ao que é ser jornalista e buscam corresponder a um modelo de consagração internalizado pelos memorialistas no início de suas carreiras, cujo ritmo de ascensão foi comprometido com o regime militar e a censura. No entanto, embora afastados de altos cargos nas grandes empresas de comunicação e jornalismo, os remanescentes de Realidade souberam canalizar talento para a Imprensa Alternativa. Por meio de suas participações nos jornais alternativos receberam um reconhecimento que lhes garantiu a condição de autores e intelectuais prestigiados. Salienta-se que tal reconhecimento foi concedido por membros da elite intelectual brasileira, seja vinculada à universidade ou a produção cultural de nicho ou especializada.

Por fim é necessário fazer algumas ponderações à guisa de dar um desfecho à argumentação. A história dos jornalistas re- 
manescentes da revista Realidade proferida nas entrevistas e descrita nas biografias e memórias demonstra que, diante das transformações ocorridas no campo jornalístico, eles permaneceram fiéis ao princípio segundo o qual o jornalismo é uma atividade intelectual. Como Mylton Severiano, um dos entrevistados, salientou, seria uma redundância a expressão jornalista intelectual. Seja como profissional da imprensa ou publicando livros, em ambos os casos, estamos tratando do trabalho de escrita profissional e esta é, por excelência, um ofício intelectual. Entretanto, se o ofício de artífice da escrita é o que define a profissão, a função de autor, por sua vez, é a que leva ao panteão de nomes consagrados na história da imprensa.

\section{REFERÊN CIAS BIBLIO GRÁFICAS}

AZEVEDO, Carlos. Cicatriz da reportagem: 13 histórias que fizeram um repórter. São Paulo: Editora Papagaio, 2007. p.404.

BAHIA, Juarez. Jornal, história técnica: história da imprensa brasileira, $4^{\mathrm{a}}$ Edição. São Paulo: Ed. Ática, 1990.p. 445.

BERGAMO, Alexandre. Reportagem, Memória e História no Jornalismo Brasileiro. Mana [online]. 2011, vol.17, n.2, p. 233-269. ISSN 0104-9313. Disponível em: <http://dx.doi.org/10.1590/S0104-93132011000200001> Acesso em: 19 agosto de 2012.

BERGAMO, Alexandre. A escrita do presente: mudanças no status cultural do jornalismo. In: MICELI, Sérgio; PONTES, Heloísa (Org.). Cultura e Sociedade. São Paulo: Ed. Edusp. 2004. p.2014-239.

BLOCH, Marc. Apologia da História ou 0 ofício do historiador. Rio de Janeiro: Ed. Zahar. 2001.

BORGES, Jorge Luis. Funes, o memorioso. In: Ficções. São Paulo: Companhia das Letras, 2007.

BOURDIEU, Pierre. A ilusão biográfica. In: Razões Práticas: sobre a teoria da ação. Campinas: Papirus, 1996. p. 74-82.

DE CERTEAU, Michel. A operação historiográfica. In: A Escrita da História. Rio de Janeiro: Forense Universitária, 2010. 
DRUMMOND DE ANDRADE, Carlos de. Ontem. In: A rosa do povo - Livro vira-vira. Rio de Janeiro: BestBolso, 2010. p. 52.

FARO, J. S. Realidade 1966-1968: Tempo de reportagem na imprensa brasileira. São Paulo: Universidade de São Paulo. 1999. p.253. Disponível em: http:// www.jsfaro.net/ Acesso em 17 de jan. 2009.

FOUCAULT, Michel. 0 que é um autor? In: Foucault, Michel; Motta, Manuel Barros da (Org.). Estética: literatura e pintura, música e cinema. Rio de Janeiro: Editora Forense Universitária, 2009. (Ditos e Escritos, v. 3).

FREIRE, Roberto. Eu é um outro: autobiografia de Roberto Freire. Salvador: Maianga, 2002. p.452.

HEYMANN, Luciana. o lugar do arquivo: a construção do legado de Darcy Ribeiro. Rio de Janeiro: Contracapa, 2012.

KARNAL, Leandro; TATSCH, Flavia Galli. A memória evanescente. In: PINSKI, Carla Bassanezi; LUCA, Tania Regina de (Orgs). 0 historiador e suas fontes. São Paulo: Contexto, 2009, p. 9-27.

KUCINSKI, Bernardo. Jornalistas e Revolucionários: nos tempos de imprensa alternativa. São Paulo: Editora da Universidade de São Paulo, 2003. p.441.

LARA, Silvia Hunold. Os documentos textuais e as fontes do conhecimento histórico. Anos 90. Porto Alegre, v.15, n.28, p.17-39, dez. 2008.

LE GOFF, Jacques. Documento/Monumento. In: História e Memória. Campinas: Editora da Unicamp, 2003. p. 525-541.

LEJEUNE, Philippe. Autobiografia e ficção. In: Noronha, Jovita Maria Gerheim (Org.). 0 pacto autobiográfico: de Rousseau à Internet. Belo Horizonte: Ed. UFMG, 2008. p.103-109.

LUCA, Tania Regina de. História dos, nos e por meio dos periódicos. In: PINSKY, Carla Bessanezi (Org). Fontes Históricas. São Paulo: Contexto, 2010. p.111153.

MICELI, Sérgio. Biografia e Cooptação ( o estado atual das fontes para a história social e política das elites no Brasil). Intelectuais à Brasileira. São Paulo: Companhia das Letras, 2001. p. 345-356.

MORAES, Vaniucha de. Realidade (Re) vista: o papel do intelectual na concepção de um projeto revolucionário. 2010. p.199. (Dissertação de Mestrado apresentada ao Programa de Pós-Graduação em Jornalismo). Universidade Federal de Santa Catarina. Santa Catarina. 
PEREIRA, Fábio Henrique. Os jornalistas-intelectuais no Brasil: identidade, práticas e transformações no mundo social. 2008. p. 469 . (Tese de Doutorado apresentada ao Programa de Pós-Graduação em Comunicação) Universidade de Brasília. Brasília.

POLLAK, Michel. Memória, Esquecimento, Silêncio. Revista Estudos Históricos. Rio de Janeiro: FGV, vol. 2, n. 3, 1989.

POLLAK, Michel. Memória e identidade social. Estudos Históricos. 1992, vol. 5, n. 10. p. 200-212.

PROST, Antoine. Doze lições sobre a história. Belo Horizonte: Autêntica Editora, 2008.

RIBEIRO, José Hamilton. Jornalistas: 1937 a 1997: história da imprensa de São Paulo pelos que batalham laudas (terminais), câmeras e microfones. São Paulo: Imprensa Oficial do Estado, 1998.

REVISTA REALIDADE. São Paulo: Editora Abril, 1966-1968. Mensal.

RICOEUR, Paul. História/Epistemologia. In: A Memória, a História, o Esquecimento. Campinas, SP: Editora Unicamp, 2007. p. 151-296.

SEVERIANO, Mylton. Realidade - história da revista que virou lenda. Florianópolis: Insular, 2013.

Data de Recebimento: 12 de dezembro de 2014

Data de Aprovação: 30 de dezembro de 2014 